\title{
Korelasi Fungsi Kepala Sekolah Sebagai EducatorDengan Kompetensi Pedagogik Guru SMA Darussalam Blokagung Tegalsari Banyuwangi
}

\author{
Moh. Mahmud ${ }^{1}$, Sugiyono², Fitriyana $^{3}$ \\ e-mail : mohmahmud060578@gmail.com ${ }^{1}$, sugiyono736@gmail.com², \\ fieyanna75@gmail.com ${ }^{3}$ \\ Prodi Manajemen Pendidikan Islam \\ Institut Agama Islam Darussalam Blokagung Banyuwangi
}

\begin{abstract}
The objectives of this study were: (1) to determine the function of the principal as an educator at SMA Darussalam Blokagung Banyuwangi, (2) to determine the pedagogical competence of SMA Darussalam Blokagung Banyuwangi teachers, (3) to determine the relationship between the principal's function as an educator and the pedagogical competence of SMA teachers. Darussalam Blokagung Banyuwangi. This study used a quantitative descriptive method with product moment correlation analysis on data validity testing and to find data reliability using the alpha formula, while for data analysis tests used qualitative analysis for questions 1 and 2 and used quantitative analysis for question number 3. The population of this study was all 43 SMA Darussalam Blokagung Tegalsari teachers in Banyuwangi. Observation data collection techniques, questionnaires and documentation. The results found that: (1) the function of the principal as an educator in SMA Darussalam Blokagung Banyuwangi was $92 \%$ which means that it has a Very Good category. (2) the pedagogical competence of teachers at SMA Darussalam Blokagung Banyuwangi is 91\%, which means it is in the Very Good category. (3) The relationship between the principal's function as an educator and the pedagogical competence of SMA Darussalam Blokagung Banyuwangi teachers is 0.599 with a percentage of 59.9\% which falls into the Enough category.
\end{abstract}

Keywords: The Function of the Principal as an Educator, Teacher Pedagogical Competence

\begin{abstract}
Abstrak
Tujuan penelitian ini yaitu: (1) untuk mengetahui fungsi kepala sekolah sebagai educator di SMA Darussalam Blokagung Banyuwangi, (2) untuk mengetahui kompetensi pedagogik guru SMA Darussalam Blokagung Banyuwangi, (3) untuk mengetahui hubungan fungsi kepala sekolah sebagai educator dengan kompetensi pedagogik guru SMA Darussalam Blokagung Banyuwangi. Penelitian ini menggunakan metode deskriptif kuantitatif dengan analisis korelasi product moment pada uji validitas data dan untuk mencari reliabilitas data menggunakan rumus alpha, sedangkan untuk uji analisis data menggunakan analisis kualitatif untuk soal nomor 1dan 2 dan menggunakan analisis kuantitatif untuk soal nomor 3. Populasi penelitian ini adalah seluruh guru SMA Darussalam Blokagung Tegalsari Banyuwangi yang berjumlah 43 orang. Teknik pengumpulan data observasi, angket dan dokumentasi. Hasil ditemukan bahwa: (1) fungsi kepala sekolah sebagai educator di SMA Darussalam Blokagung Banyuwangi sebesar 92\% yang artinya memiliki kategori Sangat Baik. (2) kompetensi pedagogik guru di SMA Darussalam Blokagung Banyuwangi sebesar 91\% yang artinya masuk dalam kategori Sangat Baik. (3) Hubungan fungsi Kepala Sekolah sebagai educator dengan kompetensi pedagogik guru SMA Darussalam Blokagung Banyuwangi sebesar 0,599 dengan persentase sebesar 59,9\% yang masuk dalam kategori Cukup.
\end{abstract}

\section{Kata Kunci: Fungsi Kepala Sekolah Sebagai Educator, Kompetensi Pedagogik Guru}

Korelasi Fungsi Kepala Sekolah Sebagai EducatorDengan Kompetensi Pedagogik

Guru SMA Darussalam Blokagung Tegalsari Banyuwangi

Moh. Mahmud, Sugiyono, Fitriyana 


\section{A. Pendahuluan}

1. Latar Belakang

Upaya dalam mewujudkan dan mensukseskan suatu lembaga satuan pendidikan merupakan tugas dan tanggung jawab seorang Kepala Sekolah. Kepala sekolah adalah seorang tenaga peranonal guru yang diberi tugas untuk memimpin sekolah, tempat diselenggarakannya proses belajar mengajar (Basri, 2014: 40). Upaya untuk memajukan dan mensukseskan keberhasilan lembaga pendidikan adalah tanggung jawab seorang kepala sekolah sebagai educator. Sebagai pendidik, kepala sekolah sangat berperan untuk meningkatkan dan menciptakan kualitas pendidikan yang bermutu. Maka, kepala sekolah harus mempunyai strategi yang tepat dalam meningkatkan kualitas tenaga kependidikan di sekolah tersebut.

Dalam proses pembelajaran guru sangatlah dituntut untuk memiliki peranan. Proses pembelajaran dapat dikatakan berhasil dan mutu pendidikan bisa meningkat apabila seorang guru mampu untuk menghayati, memahami, dan mengekpresikan profesinya sebagai seorang pendidik dan memiliki wawasan pengetahuan yang sangat luas serta keterampilan sehingga dapat menjadikan proses pembelajaran menjadi lebih efektif. Dalam hal ini, guru dituntut untuk bisa menciptakan situasi dan kondisi pembelajaran yang inovatif, kreatif dan menyenangkan.

Guru professional adalah guru yang memiliki kompetensi pedagogik yang tinggi dalam menciptakan proses pembelajaran dikelas, agar dapat menciptakan proses pembelajaran yang berkualitas bagi siswanya. Dalam peningkatan kompetensi pedagogik guru, tidak terlepas dari peran kepala sekolah sebagai educator. Sebagai educator, Kepala Sekolah juga diharapkan dapat membina dan membimbing para guru secara lebih mendalam, yang termasuk didalamnya bagaimana memahami psikologi, mental, fisik, dan nilai estetika seorang guru.

Tercapainya sebuah tujuan pendidikan sangat bergantung pada kecakapan dan kemampuan strategi kepala sekolah dalam mengatur sumber organisasi dan membimbing tenaga pendidik dalam mendidik siswa dalam mencapai tujuan 
pendidikan. Dalam hal ini, kepala sekolah dapat mengedepankan perannya sebagai educator.

Berdasarkan pengamatan sementara yang dilakukan oleh peneliti di SMA Darussalam pada tanggal 27 Februari 2019 muncul beberapa data yang ditemukan oleh peneliti ketika melakukan pengamatan diantaranya bahwa SMA Darussalam merupakan sebuah lembaga pendidikan yang sebagian besar gurunya telah melaksanakan pembelajaran yang bersifat mendidik dengan memperhatikan potensi atau kemampuan yang dimiliki oleh peserta didik di kelas tersebut. Selain itu ada hal menarik lainnya yang menarik perhatian peneliti, yaitu kualifikasi tenaga pendidik yang ada di SMA Darussalam sudah S1 dan rata-rata usia masih muda, antusias mereka sangat tinggi untuk meningkatkan kompetensi pedagogik terutama dalam menambah pengetahuan mengenai teori-teori belajar dan prinsip pembelajaran yang baik dan mendidik sehingga dapat menghasilkan banyak prestasi lomba dibidang ilmu pengetahuan yang berhasil diraih oleh siswa baik tingkat kecamatan maupun tingkat kabupaten. Namun apakah keberhasilan yang dicapai oleh guru SMA Darussalam secara umum dan siswa secara khusus karena peran kepala sekolah sebagai educator.

2. Rumusan Masalah

1) Bagaimana fungsi kepala sekolah sebagai educator di SMA Darussalam Blokagung Tegalsari Banyuwangi?

2) Bagaimana kompetensi pedagogik guru di SMA Darussalam Blokagung Tegalsari Banyuwangi?

3) Adakah hubungan fungsi kepala sekolah sebagai educator dengan kompetensi pedagogik guru SMA Darussalam Blokagung Tegalsari Banyuwangi?

3. Tujuan Penelitian

1) Untuk mengetahui fungsi peran kepala sekolah sebagai educator di SMA Darussalam Blokagung Tegalsari Banyuwangi. 
2) Untuk mengetahui kompetensi pedagogik guru di SMA Darussalam Blokagung Tegalsari Banyuwangi.

3) Untuk mengetahui hubungan fungsi kepala sekolah sebagai educator dengan kompetensi pedagogik guru SMA Darussalam Blokagung Tegalsari Banyuwangi.

4. Manfaat Peneitian

1) Teoritis

Hasil dari penelitian ini diharapkan secara umum dapat memberikan kontribusi terhadap pengembangan ilmu pengetahuan administrasi pendidikan, khususnya dalam bidang kepemimpinan kepala sekolah sebagai Educator terhadap kompetensi pedagogik guru.

2) Praktis

a) Menjadi masukan bagi stakeholder pendidikan tentang hubungan peran kepala sekolah sebagai educator dengan kompetensi pedagogik guru.

b) Memberikan kontribusi bagi pemimpin dan pengelola lembaga pendidikan Islam pada objek yang diteliti khususnya SMA Darussalam Blokagung Tegalsari Banyuwangi.

c) Menjadi barometer terkait dengan tema penelitian terhadap peneliti selanjutnya.

\section{B. Landasan Teori}

1. Pengertian Kepala Sekolah

Kepala Sekolah berasal dari dua kata, yaitu "kepala dan sekolah". Kata kepala diartikan sebagai ketua dalam suatu organisasi atau lembaga yang diimpinnya. Sedangkan sekolah adalah lembaga yang menjadi tempat terjadinya interaksi antara guru yang memberi pelajaran dan peserta didik yang menerima pelajaran. Dengan demikian dapat diartikan secara sederhana bahwa Kepala Sekolah merupakan tenaga fungsional guru yang diberi tugas untuk memimpin suatu sekolah dimana terjadinya interaksi 
antara guru yang memberi pelajaran dan peserta didik yang menerima pelajaran.

Dari definisi di atas dapat disimpulkan bahwa Kepala Sekolah merupakan pimpinan tertinggi dalam Lembaga Pendidikan yang bertanggung jawab terhadap segala sesuatu yang berhubungan dengan kelancaran jalannya sekolah demi terwujudnya tujuan dari sekolah tersebut. Oleh karena itu, suksesnya sekolah yang dipimpin tergantung pada sejauh mana pelaksanaan misi yang dibebankan diatas pundaknya, kepribadian, dan kemampuannya dalam bergaul dengan unsur-unsur yang ada didalamnya.

2. Fungsi dan Peran Kepala Sekolah

Fungsi Kepala Sekolah itu dibagi menjadi tiga, yaitu sebagai administrator pendidikan, supervisor pendidikan, dan pemimpin pendidikan. (Lazaruth, 1992: 68). Sebagai administrator pendidikan Kepala Sekolah bertugas untuk meningkatkan mutu sekolahnya dengan berpacu pada perbaikan dan mengembangkan fasilitas sekolah dalam bentuk apapun, misalnya gedung, perlengkapan atau peralatan dan lain-lain yang terakup dalam bidang administrasi pendidikan. Lalu jika Kepala Sekolah berfungsi sebagai supervisor pendidikan, berarti usaha peningkatan mutu dapat dilakukan dengan cara peningkatan mutu guru-guru dan seluruh staf sekolah, misalnya melalui rapat-rapat, observasi kelas, perpustakaan dan lain sebagainya. Selain sebagai administrator dan supervisor pendidikan, Kepala Sekolah juga berfungsi sebagai pemimpin pendidikan. Peningkatan mutu pendidikan akan berjalan dengan baik apabila guru bersifat terbuka, kreatif dan memiliki semangat kerja yang tinggi.

Menurut Mulyasa (2004: 34) Kepala Sekolah memiliki tujuh fungsi utama yaitu: (a) Kepala Sekolah sebagai Educator, (b) Kepala Sekolah sebagai Manager, (c) Kepala Sekolah sebagai Administrator, (d) Kepala Sekolah sebagai Supervisor, (e) Kepala Sekolah sebagai Leader, (f) Kepala Sekolah sebagai Inovator, (g) dan Kepala Sekolah sebagai Motivator 
Adapun peran Kepala Sekolah sebagai seorang pemimpin Lembaga Pendidikan, yaitu sebagai pelaksana (Executive), sebagai perencana (Planner), sebagai seorang ahli (expret), mengawasi hubungan antar anggota-anggota kelompok (Controller Of Internal Relationship), mewakili kelompok (Group Representative), bertindak sebagai pemberi ganjaran dan hukuman, bertindak sebagai wasit dan penengah (Arbitator And Mediator), sebagai pencipta, dan bertindak sebagai ayah (Father Figure)

3. Kepala Sekolah Sebagai Educator

Secara sederhana educator adalah pendidik, pengajar, pembina dan pelatih. Sebagai Educator tugas utama seorang kepala sekolah yaitu sebagai pemimpin yang berperan untuk menciptakan situasi, mengatur kegiatan kelompok organisasi yang dipimpin, dan menjadi juru bicara dalam kelompok. Sebagai seorang pendidik kepala sekolah harus memiliki strategi yang tepat dalam meningkatkan dan mengembangkan profesionalisme tenaga pendidik di sekolah. Kepala sekolah sebagai pendidik, harus mampu untuk menanamkan pembinaan paling tidak lima macam pembinaan, yaitu:

a. Pembinaan Mental

Pembinaan yang diarahkan untuk tenaga kependidikan. Pembinaan berkaitan dengan sikap, batin dan watak. Sebagai pendidik, kepala sekolah harus mampu menciptakan dan mengembangkan iklim sekolah yang kondusif agar setiap tenaga kependidikan dapat melaksanakan tugas dengan baik dan profesional. Untuk itu, kepala sekolah berusaha untuk melengkapi sarana prasarana yang ada di sekolah dan sumber belajar untuk memudahkan guru dalam proses berlangsungnya belajar mengajar.

b. Pembinaan Moral

Pembinaan yang diarahkan untuk membina tenaga pendidik akan halhal yang berkaitan dengan ajaran baik buruknya suatu perbuatan, sikap dan kewajiban yang sesuai dengan tugas masing-masing. Kepala sekolah yang profesional adalah kepala sekolah yang bisa memberikan arahan 
ataupun nasehat terhadap seluruh warga sekolah, misalnya saat upacara bendera atau ada acara pertemuan rutin.

c. Pembinaan Fisik

Pembinaan yang diarahkan tentang hal-hal yang berhubungan dengan kesehatan jasmani dan penampilan manusia secara lahiriah. Seorang kepala sekolah harus bisa memberikan motivasi terhadap tenaga kependidikan untuk terlibat dalam berbagai kegiatan olah raga secara aktif.

d. Pembinaan Artistik

Pembinaan yang diarahkan untuk membina tenaga pendidik akan pentingnya kepekaan manusia terhadap seni dan keindahan. Hal ini bisa dilakukan melalu kegiatan karyawisata atau berlibur yang diadakan oleh sekolah setiap akhir tahun ajaran.

e. Pembinaan Kualitas Pembelajaran

Pembinaan yang diarahkan untuk membina tenaga pendidik dalam meningkatkan dan mengembangkan kualitas pembelajaran. Adapun upaya pembinaan yang dilakukan kepala sekolah untuk guru dalam meningkatkan kualitas pembelajaran dan prestasi belajar siswa yaitu:

1. Mengikutsertakan guru-guru dalam penataran-penataran untuk menambah wawasan dan memberikan kesempatan kepada guru-guru yang ingin melanjutkan kejenjang pendidikan yang lebih tinggi.

2. Kepala sekolah berusaha menggerakkan tim evaluasi hasil belajar peserta didik.

3. Menggunakan waktu secara efektif di sekolah.

\section{Kompetensi Guru}

Menurut Irwanto (2016: 12) kompetensi merupakan kemampuan untuk melaksanakan sesuatu yang diperoleh melalui pendidikan dan pelatihan yang bersifat kognitif, efektif dan performen. Berdasarkan UndangUndang Nomor 14 tahun 2005 tentang guru dan dosen pada bab IV Pasal 10 menyebutkan ada empat kompetensi yang harus dimiliki oleh guru, yaitu 
kompetensi pedagogik, kompetensi kepribadian, kompetensi profesional, dan kompetensi sosial. Keempat kompetensi tersebut tidak bisa berdiri sendiri, melainkan saling berhubungan dan saling mempengaruhi, serta saling mendasari satu sama lain.

Berdasarkan penjelasan pasal 10 ayat (1) tersebut, maksud dari empat kompetensi yang wajib dimiliki oleh guru dikemukakan sebagai berikut.

a. Kompetensi pedagogik

Kompetensi pedagogik adalah kemampuan mengelola pembelajaran peserta didik.

b. Kompetensi Kepribadian

Kompetensi Kepribadian adalah kemampuan kepribadian yang mantap, berakhlak mulia, arif, dan berwibawa serta menjadi teladan peserta didik.

c. Kompetensi Profesional

Kompetensi profesional adalah kemampuan penguasaan materi pembelajaran secara luas dan mendalam.

d. Kompetensi Sosial

Kompetensi Sosial adalah kemampuan guru untuk berkomunikasi dan berinteraksi secara efektif dan efisien dengan peserta didik, sesama guru, orang tua/ wali peserta didik dan masyarakat sekitar.

Upaya yang dapat dilakukan oleh guru dalam meningkatkan dan mengembangkan keempat kompetensi itu antara lain seperti dengan meningkatkan jenjang pendidikan ke arah yang lebih tinggi secara relevan dan linear, mengikuti diklat, aktif mengikuti berbagai kegiatan dalam KKG/ MGMP, mengikuti seminar pendidikan, dan giat membaca buku-buku profesional.

5. Kompetensi Pedagogik Guru

Menurut Sadulloh (2010: 2) pedagogik adalah ilmu yang mempelajari masalah membimbing anak menuju tujuan yang dituju. Kompetensi Pedagogik merupakan kemampuan yang dimiliki seorang guru dalam 
menciptakan pembelajaran yang kondusif. Jadi, kompetensi pedagogik adalah kompetensi yang sangat penting untuk dimiliki seorang guru, terutama untuk memahami karakteristik peserta didik, mengelola pembelajaran, dan mengembangkan potensi peserta didik.

a. Menguasai Karakteristik Peserta Didik

Dalam hal ini, penguasaan karakteristik peserta didik sangatlah berperan penting dalam berlangsungnya proses belajar mengajar.

Menurut Mukhtar dan Iskandar dalam Irwanto (2016: 52) bahwa beberapa manfaat yang dapat diperoleh oleh guru akan pentingnya memahami karakteristik peserta didik di kelas, yaitu:

1. Guru memperoleh pandangan yang lengkap tentang kemampuan awal peserta didik.

2. Guru akan memperoleh gambaran jenis pengalaman peserta didik.

3. Guru dapat memahami latar belakang peserta didik tersebut, termasuk latar belakang keluarga.

4. Guru dapat mengetahui perkembangan dan pertumbuhan peserta didik, baik jasmaniah ataupun rohaniah.

5. Guru dapat mengetahui kebutuhan peserta didik.

6. Guru dapat mengetahui tingkat pengetahuan yang diperoleh peserta didik.

7. Guru dapat mengetahui penguasaan bahasa peserta didik, baik secara lisan maupun tertulis.

8. Guru dapat mengetahui sikap dan nilai yang menjiwai diri peserta didik.

b. Menguasai Teori Belajar dan Prinsip-Prinsip Pembelajaran Yang Mendidik

Penguasaan dalam teori belajar dan prinsip-prinsip pembelajaran yang mendidik dapat mewujudkan proses pembelajaran yang efektif, efisien dan optimal. Adapun manfaat dari seorang guru yang bisa 
menguasai teori belajar dan prinsip-prinsip pembelajaran yang mendidik yaitu:

1. Guru dapat memahami apa dan bagaimana sebenarnya proses belajar itu terjadi. Sehingga guru dapat mengambil tindakan pedagogik dan edukatif yang tepat bagi penyelenggara pendidikan.

2. Guru dapat memilih dan menggunakan pendekatan yang tepat untuk menciptakan proses pembelajaran yang kondusif.

3. Guru dapat memahami dan menerapkan sejumlah implikasi konstruktif dari teori belajar dan prinsip-prinsip pembelajaran yang mendidik bagi kepentingan efektivitas dan keberhasilan pembelajaran.

4. Guru dapat memiliki dan mengembangkan sikap peserta didik untuk meningkatkan dan mengembangkan kualitas belajar peserta didik tersebut.

5. Guru dapat terhindar dari persepsi dan perspektif yang tidak tepat terhadap proses berlangsungnya belajar peserta didik.

6. Guru dapat mewujudkan kinerja yang optimal dalam menguasai teori dan prinsip-prinsip pembelajaran yang mendidik.

c. Pengembangan Kurikulum

Dalam sistem pendidikan, kurikulum memiliki peranan yang penting. Berdasarkan hal tersebut, pengembangan kurikulum harus berorientasi pada tujuan pendidikan yang jelas, proses pembelajaran yang benar, pandangan tentang lingkungan yang konstruktif, peranan guru yang aktif, dan sistem evaluasi yang valid. Dalam hal ini, diharapkan dengan adanya pengembangan kurikulum disetiap jenjang pendidikan akan mendapatkan tujuan dan mutu pendidikan yang ingin dicapai.

Indikator kompetensi pengembangan kurikulum yang wajib dilaksanakan oleh guru yaitu:

1. Guru telah menyusun RPP sesuai dengan silabus dalam kurikulum sekolah. 
2. Guru menyampaikan materi pembelajaran dengan lancar, jelas dan tepat.

3. Guru dapat menyesuaikan materi yang diajarkan dengan tingkat perkembangan peserta didik.

4. Guru menghubungakan materi yang disampaikan dengan kehidupan sehari-hari peserta didik.

5. Materi yang diajarkan adalah materi yang mutakhir.

6. Guru membantu mengembangkan kemampuan dan keterampilan peserta didik.

d. Kegiatan Pembelajaran Yang Mendidik

Peningkatan mutu pendidikan merupakan suatu upaya yang penting dalam pelaksanaan pendidikan, khususnya di Sekolah. Dalam meningkatkan mutu pendidikan, guru akan berupaya untuk menyempurnaan kurikulum dan proses pembelajaran yang dilakukan.

Adapun indikator kompetensi pada kegiatan pembelajaran yang mendidik yaitu:

1. Guru melaksanakan aktifitas pembelajaran sesuai dengan rancangan.

2. Guru melaksanakan aktivitas pembelajaran untuk membantu berlangsungnya proses pembelajaran.

3. Guru dapat menyikapi kesalahan peserta didik sebagai tahapan dalam proses pembelajaran, bukan karena suatu kesalahan yang perlu untuk dikoreksi.

4. Guru melaksanakan kegiatan pembelajaran yang sesuai dengan kurikulum.

5. Guru dapat menciptakan iklim kelas yang efektif.

6. Guru dapat menyesuaikan aktifitas pembelajaran dengan kondisi kelas.

7. Guru memberikan kesempatan kepada peserta didik untuk bertanya.

8. Guru menggunakan alat bantu mengajar, atau audio-visual untuk meningkatkan motivasi belajar peserta didik.

e. Pengembangan Potensi Peserta Didik

Korelasi Fungsi Kepala Sekolah Sebagai EducatorDengan Kompetensi Pedagogik

Guru SMA Darussalam Blokagung Tegalsari Banyuwangi

Moh. Mahmud, Sugiyono, Fitriyana 
Pengembangan potensi peserta didik merupakan upaya yang terpenting dalam dunia pendidikan. Pentingnya pengembangan dalam potensi peserta didik yaitu agar peserta didik memiliki kemampuan untuk meningkatkan spiritual ilmu keagamaan, pengendalian diri, kecerdasan, akhlak mulia, kepribadian, dan keterampilan.

Indikator kompetensi pengembangan potensi peserta didik dinyatakan sebagai berikut.

1. Guru menganalisis hasil belajar siswa berdasarkan dengan segala bentuk penilaian untuk dapat mengetahui tingkat kemajuan peserta didik.

2. Guru merancang dan melaksanakan aktifitas pembelajaran sesuai dengan RPP dan Kurikulum.

3. Guru secara aktif memperhatikan peserta didik dalam proses berlangsungnya pembelajaran dengan memberikan perhatian antar individu.

4. Guru memberikan kesempatan belajar untuk peserta didik.

5. Guru memusatkan perhatian dan mendorongnya untuk menggunakan informasi yang sudah disampaikan.

f. Komunikasi dengan Peserta Didik

Berkomunikasi dengan peserta didik sangatlah penting untuk guru dalam proses berlangsungnya pembelajaran. Dengan berkomunikasi, guru dapat menyampaikan gagasan, informasi dan harapan dari penjelasan materi yang sudah disampaikan. Komunikasi yang baik sangat diperlukan dalam dunia pendidikan.

Adapun kompetensi yang ada pada komunikasi dengan peserta didik adalah sebagai berikut.

1. Guru menggunakan pertanyaan untuk mengetahui pemahaman dan menjaga partisipasi peserta didik.

2. Guru memberikan pertanyaan dan mendengarkan tanggapan yang sudah disampaikan oleh peserta didik. 
3. Guru menanggapi pertanyaan peserta didik secara benar sesuai dengan tujuan kurikulum.

4. Guru menyediakan kegiatan pembelajaran yang bisa menumbuhkan kerjasama yang baik antar peserta didik.

g. Penilaian dan Evaluasi

Evaluasi merupakan proses yang sangat penting dalam kegiatan belajar formal. Bagi guru, evaluasi dapat dijadikan efektifitas kinerjanya selama ini. Dengan kegiatan evaluasi akan ditentukan nasib peserta didik untuk selanjutnya. Karena dengan adanya kegiatan evaluasi, maka akan terukur seberapa besar kemampuan yang sudah dimiliki oleh peserta didik tersebut.

Indikator dari kompetensi penilaian dan evaluasi yang harus dimiliki oleh guru adalah sebagai berikut.

1. Guru menyusun alat penilaian yang sesuai dengan tujuan pembelajaran.

2. Guru melaksanakan evaluasi dengan berbagai cara dan jenis penilaian.

3. Guru menganalisis hasil penilaian dan evaluasi tersebut untuk mengetahui seberapa besar kekuatan dan kelemahan yang dimiliki oleh masing-masing peserta didik.

4. Guru memanfaatkan masukan dari peserta didik untuk meningkatkan pembelajaran selanjutnya.

5. Guru memanfaatkan hasil penilaian untuk menyusun rancangan pembelajaran selanjutnya.

6. Kajian terdahulu

1) Penelitian yang dilakukan oleh Mira Maulida (2018), dengan judul Peran Kepala Sekolah dalam Meningkatkan Kompetensi Pedagogik Guru MTsN 4 Aceh Selatan. Penelitian yang digunakan adalah jenis penelitian lapangan (field research) yang bersifat diskriptif kualitatif. Teknik pengumpulan data yang digunakan adalah observasi, 
wawancara dan dokumentasi. Sedangkan untuk teknik analisis data, peneliti menggunakan teknik analisis triangulasi. Adapun hasil penelitian ini menunjukkan bahwa berdasarkan hasil wawancara yang telah peneliti lakukan dengan Kepala Sekolah, dewan guru, dan siswa dapat dilihat bahwa tanpa adanya peran Kepala Sekolah dalam membimbing dan mengarahkan guru, maka kompetensi pedagogik tidak akan meningkat. Adapun persamaan dalam penelitian ini dengan penelitian peneliti yaitu, sama-sama membahas peran Kepala Sekolah daam meningkatkan kompetensi pedagogik guru. Sedangkan perbedaannya yaitu peneliti menggunakan jenis penelitian Kuantitatif.

2) Penelitian yang digunakan oleh Jahiriansyah (2013), dengan judul Peran Kepala Sekolah Sebagai Pendidik Dalam Meningkatkan Kompetensi Pedagogik Guru SD Negeri 07 Delta Pawan Ketapang. Penelitian yang digunakan adalah jenis penelitian kualitatif deskriptif dengan desain studi kasus. Hasil dari penelitian ini adalah peran Kepala Sekolah sebagai pendidik dalam meningkatkan kompetensi pedagogik guru SD Negeri 07 Kecamatan Delta Pawan Ketapang yaitu kegiatan bimbingan dalam penguasaan karakteristik peserta didik, penguasaan teori dan prinsip pembelajaran, pengembangan kurikulum, pembelajaran yang mendidik, pengembangan potensi peserta didik, komunikasi efektif dengan peserta didik, serta pelaksanaan evaluasi pembelajaran. Adapun persamaan dalam penelitian ini dengan penelitian peneliti yaitu, sama-sama membahas peran Kepala Sekolah daam meningkatkan kompetensi pedagogik guru. Sedangkan perbedaannya yaitu peneliti menggunakan jenis penelitian Kuantitatif.

3) Penelitian yang dilakukan Parriz Aslam (2018), Pengaruh Kepemimpinan Kepala Madrasah terhadap Peningkatan Kompetensi Guru pada MI AlMuawanah 1 Barurejo Siliragung Banyuwangi. Penelitian ini menggunakan metode penelitian kuantitatif dengan jenis diskiptif kuantitatif sedangkan untuk teknik pengumpulan data menggunakan 
metode angket, observasi, wawancara dan dokumentasi. Sedangkan untuk analisis datanya menggunakan analisis statistik. Adapun hasil penelitiannya yaitu adanya pengaruh kepemimpinan kepala madrasah terhadap peningkatan kompetensi guru di MI Al Muawanah 1 Barurejo Siliragung Banyuwangi tahun ajaran 2017/2018 sebesar 66,6\% sedangkan untuk sisanya 33,4\% dipengaruhi oleh variabel lain.

C. Metode Penelitian

1. Jenis penelitian ini deskriptif kuantitatif

2. Populasi yang digunakan dalam penelitian ini bersifat penalitian populasi karena jumlah subjek kurang dari 100

3. Teknik pengumpulan data yang digunakan adalah kuesioner, observasi dan dokumentasi

4. Validitas data menggunakan rumus korelasi product moment.

5. Reliabilitas data menggunakan rumus Alpha

6. Analisis data menggunakan analisis kualitatif untuk menjawab rumusan masalah nomor 1 dan 2 dan analisis kuantitatif untuk menjawab rumusan masalah nomor 3 dengan menggunakan rumus korelasi product moment.

\section{Hasil dan Pembahasan}

1) Uji Validitas

Uji validitas merupakan langkah untuk menguji apakah instrumen yang digunakan dapat mengukur apa yang seharusnya diukur atau tidak. Dalam hal ini uji validitas dilakukan dengan pengujian menggunakan rumus product moment. Yaitu dengan membandingkan $r_{\text {hitung }}$ dan $r_{\text {tabel }}$ Apabila $r_{\text {hitung }}$ lebih besar dari $r_{\text {tabel }}$, maka perbedaan yang ada adalah signifikan, sehingga instrumen dikatakan valid. Tingkat signifikan kepada uji $r$ adalah 0,05 atau 5\% hasil uji validitas terhadap instrumen penelitian korelasi strategi promosi pendidikan dengan minat peserta didik baru dikatakan valid, karena $r_{\text {hitung }}$ lebih besar dari $r_{\text {tabel }}$.

Korelasi Fungsi Kepala Sekolah Sebagai EducatorDengan Kompetensi Pedagogik Guru SMA Darussalam Blokagung Tegalsari Banyuwangi

Moh. Mahmud, Sugiyono, Fitriyana 
Tabel 1

Hasil Uji Validitas Variabel X

\begin{tabular}{|l|l|l|l|l|}
\hline No & Pertanyaan & $\begin{array}{l}\text { Corrected item-total } \\
\text { correlation }\end{array}$ & $\begin{array}{l}\text { r tabel } \\
\mathbf{( 5 \% )}\end{array}$ & Kriteria \\
\hline 1 & $\mathrm{X} 1$ & 0,446 & $>308$ & Valid \\
\hline 2 & $\mathrm{X} 2$ & 0,616 & $>308$ & Valid \\
\hline 3 & $\mathrm{X} 3$ & 0,518 & $>308$ & Valid \\
\hline 4 & $\mathrm{X} 4$ & 0,329 & $>308$ & Valid \\
\hline 5 & $\mathrm{X} 5$ & 0,616 & $>308$ & Valid \\
\hline 6 & $\mathrm{X} 6$ & 0,557 & $>308$ & Valid \\
\hline 7 & $\mathrm{X} 7$ & 0,370 & $>308$ & Valid \\
\hline 8 & $\mathrm{X} 8$ & 0,575 & $>308$ & Valid \\
\hline 9 & $\mathrm{X} 9$ & 0,336 & $>308$ & Valid \\
\hline 10 & $\mathrm{X} 10$ & 0,570 & $>308$ & Valid \\
\hline 11 & $\mathrm{X} 11$ & 0,616 & $>308$ & Valid \\
\hline 12 & $\mathrm{X} 12$ & 0,533 & $>308$ & Valid \\
\hline 13 & $\mathrm{X} 13$ & 0,446 & $>308$ & Valid \\
\hline 14 & $\mathrm{X} 14$ & 0,498 & $>308$ & Valid \\
\hline 15 & $\mathrm{X} 15$ & 0,427 & $>308$ & Valid \\
\hline
\end{tabular}

Sumber Data: Hasil Olahan Peneliti

Tabel 2

Hasil Uji Validitas Variabel Y

\begin{tabular}{|l|l|l|c|l|}
\hline No & Pertanyaan & $\begin{array}{l}\text { Corrected item-total } \\
\text { correlation }\end{array}$ & $\begin{array}{c}\text { r tabel } \\
\mathbf{( 5 \% )}\end{array}$ & Kriteria \\
\hline 1 & Y1 & 0,530 & $>0,308$ & Valid \\
\hline 2 & Y2 & 0,586 & $>0,308$ & Valid \\
\hline 3 & Y3 & 0,575 & $>0,308$ & Valid \\
\hline 4 & Y4 & 0,481 & $>0,308$ & Valid \\
\hline 5 & Y5 & 0,502 & $>0,308$ & Valid \\
\hline 6 & Y6 & 0,600 & $>0,308$ & Valid \\
\hline 7 & Y7 & 0,624 & $>0,308$ & Valid \\
\hline 8 & Y8 & 0,585 & $>0,308$ & Valid \\
\hline 9 & Y9 & 0,515 & $>0,308$ & Valid \\
\hline 10 & Y10 & 0,608 & $>0,308$ & Valid \\
\hline 11 & Y11 & 0,614 & $>0,308$ & Valid \\
\hline 12 & Y12 & 0,565 & $>0,308$ & Valid \\
\hline 13 & Y13 & 0,506 & $>0,308$ & Valid \\
\hline 14 & Y14 & 0,534 & $>0,308$ & Valid \\
\hline 15 & Y15 & 0,376 & $>0,308$ & Valid \\
\hline
\end{tabular}

Sumber Data: Hasil Olahan Peneliti

Korelasi Fungsi Kepala Sekolah Sebagai EducatorDengan Kompetensi Pedagogik Guru SMA Darussalam Blokagung Tegalsari Banyuwangi

Moh. Mahmud, Sugiyono, Fitriyana 
Berdasarkan data di atas diketahui bahwa semua pengujian terhadap instrumen variabel $\mathrm{X}$ dan $\mathrm{Y}$ menunjukkan bahwa seluruh pernyataan yang diajukan valid. Nilai $r_{\text {tabel }}$ untuk taraf signifikansi 0,05 atau $5 \%$ dan $\mathrm{N} 43-$ $2=41$ adalah 0,308 dengan demikian semua pernyataan dalam kuesioner dapat dipercaya dan dapat digunakan untuk mengumpulkan data yang diperlukan.

2) Uji Reliabilitas

Suatu instrumen dikatakan reliabel apabila instrumen tersebut digunakan untuk mengukur gejala atau objek yang sama dari satu kali akan diperoleh hasil yang sama atau konstan. Pengujian reliabilitas dilakukan dengan menggunakan teknik Cronbach Alfa sehingga data dapat dikatakan reliabel jika nilai data variabel taraf signifikansinya di bawah 0,05 .

Tabel 3

Hasil Uji Reliabilitas Data

\begin{tabular}{|c|l|c|c|}
\hline No & \multicolumn{1}{|c|}{ Variablel } & Cronbach Alpha & Kriteria \\
\hline 1. & $\begin{array}{l}\text { Fungsi Kepala Sekolah } \\
\text { Sebagai Educator }\end{array}$ & 0,636 & Cukup \\
\hline 2. & $\begin{array}{l}\text { Kompetensi Pedagogik } \\
\text { Guru }\end{array}$ & 0,832 & Kuat \\
\hline
\end{tabular}

3) Fungsi Kepala Sekolah Sebagai Educator (X)

Sesuai dengan apa yang diuraikan pada bagian sebelumnya bahwa permasalahan pertama yang dipertanyakan dalam penelitian ini adalah bagaimana fungsi Kepala Sekolah sebagai educator di SMA Darussalam Blokagung Tegalsari Banyuwangi tahun pembelajaran 2018/2019, hasil penelitian ini menunjukkan menunjukkan bahwa tingkat prosentase variabel $\mathrm{X}$ berhasil dicapai adalah sebesar $92 \%$. Jika dilihat pada tabel indeks konfirmasi nilai angket, maka nilai tersebut berada pada interval $81 \%$ sampai dengan 100\% dengan kategori sangat kuat. Dengan demikian menunjukkan bahwa 
fungsi Kepala Sekolah sebagai educator di SMA Darussalam Blokagung Tegalsari Banyuwangi tahun pembelajaran 2018/2019 tergolong sangat baik.

4) Kompetensi Pedagogik Guru

Sesuai dengan apa yang diuraikan pada bagian sebelumnya bahwa permasalahan pertama yang dipertanyakan dalam penelitian ini adalah bagaimana kompetensi pedagogik guru di SMA Darussalam Blokagung Tegalsari Banyuwangi tahun pembelajaran 2018/2019, hasil penelitian ini menunjukkan bahwa tingkat prosentase variabel $\mathrm{Y}$ yang berhasil dicapai adalah sebesar $91 \%$. Jika dilihat pada tabel indeks konfirmasi nilai angket, maka nilai tersebut berada pada interval $81 \%$ sampai dengan $100 \%$ dengan kategori sangat kuat. Hal ini menunjukkan bahwa kompetensi pedagogik guru SMA Darussalam Blokagung Tegalsari Banyuwangitahun pembelajaran 2018/2019 tergolong sangat baik.

5) Hubungan Fungsi Kepala Sekolah Sebagai Educator (X) dengan Kompetensi Pedagogik Guru

Permasalahan yang ketiga yang ingin dijawab dalam penelitian ini adalah hubungan fungsi Kepala Sekolah sebagai educator (X) dengan kompetensi pedagogik guru (Y). Berdasarkan dari data yang ada, diketahui bahwa $r_{\text {hitung }}$ sebesar 0,599 sedangkan nilai $r_{\text {tabel }}(\mathrm{dk}=\mathrm{n}-2=43-2=41)$ sehingga $r_{\text {tabel }}=0,308$. Karena $r_{\text {hitung }}$ lebih besar dari $r_{\text {tabel }}$ atau 0,599> 0,308, maka dapat disimpulkan bahwa ada hubunagan yang signifikan antara variabel fungsi Kepala Sekolah sebagai educator dengan kompetensi pedagogik guru SMA Darussalam Blokagung Tegalsari Banyuwangi tahun pembelajaran 2018/2019.

\section{E. Kesimpulan}

1. Berdasarkan hasil angket variabel X fungsi Kepala Sekolah sebagai educator di SMA Darussalam Blokagung Tegalsari Banyuwangi diperoleh hasil hitung sebesar 92\% yang termasuk kategori Sangat Baik.

Korelasi Fungsi Kepala Sekolah Sebagai EducatorDengan Kompetensi Pedagogik Guru SMA Darussalam Blokagung Tegalsari Banyuwangi

Moh. Mahmud, Sugiyono, Fitriyana 
2. Berdasarkan hasil angket variabel $\mathrm{Y}$ kompetensi pedagogik guru SMA Darussalam Blokagung Tegalsari Banyuwangi diperoleh hasil hitung sebesar 91\% yang termasuk kategori Sangat Baik.

3. Ha "Ada Hubungan Fungsi Kepala Sekolah Sebagai Educator dengan Kompetensi Pedagogik Guru SMA Darussalam Blokagung Tegalsari Banyuwangi Tahun Pembelajaran 2018/2019" diterima, karena taraf hubungannya sebesar 0,599 lebih besar dari $t_{\text {tabel }}$ dengan taraf signifikan 5\% dengan jumlah responden $43=0,308$ maka $H_{O}$ ditolak. Sehingga bisa dikatakan $r_{\text {hitung }}$ lebih besar dari $r_{\text {tabel }}$ atau $0,599 \geq 0,308$. Dan setelah dikonfirmasikan dengan $r_{\text {tabel }}$ interpretasi terletak pada 0,40 - 0,60. Artinya ada hubungan yang Cukup dari Hubungan Fungsi Kepala Sekolah Sebagai Educator dengan Kompetensi Pedagogik Guru SMA Darussalam Blokagung Tegalsari Banyuwangi Tahun Pembelajaran 2018/2019.

\section{F. Daftar Pustaka}

Arikunto, suharsimi. 2010. Prosedur Penelitian. Jakarta: Rineka Cipta

Basri Hasan dan Tatang S. 2015. Kepemimpinan Pendidikan. Bandung: Pustaka Setia.

Basri Hasan. 2014. Kepemimpinan Kepala Sekolah. Bandung: Pustaka Setia.

Daryanto. 2011. Kepala Sekolah Sebagai Pemimpin Pembelajaran. Yogyakarta: Gava Media.

Djamarah. 2010. Strategi Belajar Mengajar. Jakarta: Rineka Cipta.

E- Mulyasa.2007. Menjadi Guru Profesional (Menciptakan Pembelajaran Kreatif dan Menyenangkan). Bandung: Balai Pustaka.

Irwanto Nur. 2016. Kompetensi Pedagogik. Sidoarjo: Genta Group Production.

Kompri. 2015. Manajemen Sekolah. Yogyakarta: Pustaka Pelajar. 
Lazaruth Soewadji. 1992. Kepala Sekolah dan Tanggung Jawabnya. Yogyakarta: Kanisius

Mulyasa. 2003. Menjadi Kepala Sekolah Profesional: dalam konteks menyukseskan MBS dan KBK. Bandung: Remaja Rosdakarya

Nasrul HS. 2014. Profesi dan Etika Keguruan. Sleman Yogyakarta: Aswaja Pressindo.

Sugiyono. 2016. Metode Penelitian, Kuantitatif, Kualitatif dan R\&D. Bandung: Alfabeta.

Ahmad Sudrajat. 2008. Pengertian Pendekatan Strategi, Metode, Teknik, dan Model Pembelajaran. Bandung: Sinar Baru Algensindo

Tim Dosen Administrasi Pendidikan. 2011. Manajemen Pendidikan. Bandung: Alfabeta.

Undang-Undang RI No.20 Tahun 2003 SISDIKNAS Sistem Pendidikan Nasional \& Peraturan Pemerintah RI No.47 Tahun 2008 Wajib Belajar Edisi Lengkap. Bandung: Rhusty Publisher.

Usman, Uzer, 2002. Menjadi Guru Profesional. Bandung: Remaja Rosdakarya. 